University of Nebraska - Lincoln

DigitalCommons@University of Nebraska - Lincoln

1995

\title{
Yield and Nitrogen Use Efficiency of Irrigated Corn in the Northern Great Plains
}

Brian J. Wienhold

USDA-ARS, Brian.Wienhold@ars.usda.gov

Todd P. Trooien

USDA-ARS

George A. Reichman

USDA-ARS

Follow this and additional works at: https://digitalcommons.unl.edu/usdaarsfacpub

Wienhold, Brian J.; Trooien, Todd P.; and Reichman, George A., "Yield and Nitrogen Use Efficiency of Irrigated Corn in the Northern Great Plains" (1995). Publications from USDA-ARS / UNL Faculty. 1179. https://digitalcommons.unl.edu/usdaarsfacpub/1179

This Article is brought to you for free and open access by the U.S. Department of Agriculture: Agricultural Research Service, Lincoln, Nebraska at DigitalCommons@University of Nebraska - Lincoln. It has been accepted for inclusion in Publications from USDA-ARS / UNL Faculty by an authorized administrator of DigitalCommons@University of Nebraska - Lincoln. 


\title{
Yield and Nitrogen Use Efficiency of Irrigated Corn in the Northern Great Plains
}

\author{
Brian J. Wienhold,* Todd P. Trooien, and George A. Reichman
}

\begin{abstract}
Nitrogen and water are the two most common limitations to crop production in the semiarid northern Great Plains. Little is known about $\mathrm{N}$ use efficiency by irrigated corn (Zea mays $\mathrm{L}$.) in this region. A study was conducted to determine how irrigation and $\mathrm{N}$ fertility levels affect growth and $\mathbf{N}$ use efficiency by corn. Corn was grown under three irrigation levels: precipitation plus irrigation equal to one, two, and three tinies the calculated evapotranspiration (ET) rate. Fertilizer use efficiency was determined using ${ }^{15} \mathrm{~N}$-enriched fertilizer applied at rates equivalent to 100 and $200 \mathrm{~kg} \mathrm{~N} \mathrm{ha}{ }^{-1}$. Grain and dry matter yields, $\mathrm{N}$ content, and utilization of fertilizer $\mathbf{N}$ all exhibited yearly variations, probably the result of annual weather patterns, especially temperature. For years when temperatures during the growing season were below the 30-yr average and affected corn growth, there were no differences in yields and $\mathbf{N}$ content between the two fertility levels. For years when temperatures during the growing season were warm enough for favorable growth, corn responded to increasing $\mathrm{N}$ fertility with $60 \%$ greater yields, $75 \%$ greater $N$ content, and $60 \%$ greater percentage $N$ derived from fertilizer with the higher $\mathbf{N}$ fertility treatment. Averaged across rates, grain utilized $35 \%$ and stover an additional $15 \%$ of the applied fertilizer, while $30 \%$ remained in the upper $0.6 \mathrm{~m}$ of the soil profile at the end of the growing season. Twenty percent of the applied fertilizer could not be accounted for, lost to leaching or denitrification. Supplemental irrigation and $\mathrm{N}$ fertilization are viable management practices available to producers in the semiarid northern Great Plains.
\end{abstract}

Tack of aVailable water often limits crop productivLity in the northern Great Plains. Supplemental irrigation is a management tool available to farmers for increasing productivity. However, many soils in the northern Great Plains have been considered unsuitable for irrigation because of the presence of a slowly permeable

USDA-ARS, Northern Great Plains Res. Lab., P.O. Box 459, Mandan, ND 58.554-0459. Received 18 Jan. 1995. *Corresponding author.

Published in Agron. J. 87:842-846 (1995). subsoil. Soils are classified as nonirrigable when the subsoil has a hydraulic conductivity $<20 \%$ of the weighted hydraulic conductivity of the overlying soil layers and the slowly permeable layer is within $1.8 \mathrm{~m}$ of the surface (U.S. Dep. of Interior, Bur. of Reclamation, 1993). Irrigation water almost always has a greater salt content than does natural precipitation. Salts added to soil from irrigation water can accumulate as water is evapotranspired from soil. To prevent salt accumulation, sufficient water (precipitation or irrigation) must be added to leach salt from the crop root zone. The presence of a slowly permeable subsoil may result in a perched water table when water is applied to meet the leaching requirement.

Adequate drainage capacity has been demonstrated in situ, using large nonweighing lysimeters $(2.5 \mathrm{~m}$ square by $2.3 \mathrm{~m}$ deep), for two sites having fine-textured subsoils classified as nonirrigable using Bureau of Reclamation criteria (Doering et al., 1986; Trooien and Reichman, 1990). The drainage capacity of these soils was sufficient to prevent development of a perched water table above the finetextured subsoil even when irrigation water was applied at rates three times evapotranspiration (ET) (Trooien and Reichman, 1993). In addition, extensive areas of southern Alberta with similar soils have been irrigated for $60 \mathrm{yr}$ or more with no significant salinity problems (Chang et al., 1985).

Nonirrigated corn dry matter yields are 53 to $85 \%$ of those of corn receiving supplemental irrigation on soils similar to those in the lysimeter study discussed above (S.D. Merrill, unpublished data, 1987). These results suggest that supplemental irrigation is a feasible technology on many northern Great Plains soils. Previous research on soils with fine-textured subsoils in the northern Great

Abbreviations: ET, evapotranspiration; \% NDFF, percentage of plant $\mathrm{N}$ derived from fertilizer; \%UFN, percentage utilization of fertilizer $\mathrm{N}$. 
Plains has concentrated on the drainage capacity of these soils. Fertilizer use efficiency and environmental fate of applied fertilizer under irrigation have not been studied.

The most intensively studied fertilizer element is $\mathrm{N}$. Corn requires a large amount of $\mathrm{N}$, which commonly limits yields. Nitrogen is a component of proteins and nucleic acids and, when $\mathrm{N}$ is suboptimal, growth is reduced (Marschner, 1986). Corn is able to utilize either $\mathrm{NH}_{4}$ or $\mathrm{NO}_{3}$ as an $\mathrm{N}$ source and grows best when both are present (Schrader et al., 1972). Nitrate $\mathbf{N}$ is formed by nitrification of applied fertilizer and by mineralization and nitrification of soil organic matter. The predominant form of available $\mathrm{N}$ in most soils is $\mathrm{NO}_{3}-\mathrm{N}$. Nitrate $\mathrm{N}$ is highly soluble in water and, hence, is susceptible to leaching, potentially contributing to environmental contamination. Additional fertilizer $\mathrm{N}$ can be lost via denitrification, especially from moist soils. Denitrification losses reduce fertilizer use efficiency and are an environmental concern for the potential role $\mathrm{N}_{2} \mathrm{O}$ may play in stratospheric ozone depletion (Keeney, 1982).

The purpose of this study was to assess irrigation and fertilizer $\mathrm{N}$ effects on $\mathrm{N}$ use efficiency by corn grown on soil with slowly permeable subsoils in the semiarid northern Great Plains.

\section{MATERIALS AND METHODS}

A field study was conducted at the Menoken Township research site (T139N, R78W, Sec. 19, SE 1/4), $50 \mathrm{~km}$ east of Bismarck in Burleigh County, North Dakota. Soils at the site are Parshall (coarse-loamy, mixed Pachic Haploborolls) and Roseglen (fine-loamy, mixed, Pachic Haploborolls). These soils developed on aeolian-lacustrine sediments deposited over fine lacustrine sediments below a depth of $1.5 \mathrm{~m}$ (Doering et al., 1986). Texture of these soils is loam and sandy loam from 0 to $1 \mathrm{~m}$, with a silty clay subsoil from 1 to $1.5 \mathrm{~m}$. These soils have a $\mathrm{pH}$ of 7.7 and are well-drained, with a water table no shallower than $13 \mathrm{~m}$ below the soil surface.

Eighteen galvanized iron cylinders $(0.45 \mathrm{~m}$ diam. by $0.89 \mathrm{~m})$ were pressed into the soil using a hydraulic press. These cylinders were positioned adjacent to 18 nonweighing lysimeters being used to assess the effect of $\mathrm{N}$ fertility and irrigation level on corn yield (Reichman and Trooien, 1993). The 18 cylinders received the same $\mathrm{N}$ fertility and irrigation treatments as the adjacent lysimeters.

Each spring the soil in each plot was rototilled to incorporate plant residues and corn was planted between 17 and 26 May and thinned to a density of 62400 plants ha ${ }^{-1}$. This corresponded to one corn plant per cylinder. Corn hybrids grown were Pioneer 3978 (1984 and 1985) and Pioneer 3906 (1986 to 1988).

Prior to planting, sufficient ${ }^{15} \mathrm{~N}$-enriched $\mathrm{KNO}_{3}$ was added as an aqueous solution to each cylinder so that the added $\mathrm{N}$ plus the inorganic $\mathrm{N}$ present in the top $0.6 \mathrm{~m}$ of soil (determined by soil testing prior to planting) was equivalent to the desired $\mathbf{N}$ fertility level (100 or $\left.200 \mathrm{~kg} \mathrm{~N} \mathrm{ha}^{-1}\right)$. Due to late sampling and overestimation of $\mathbf{N}$ requirements the $\mathrm{N}$ fertility treatments in 1984 were actually 166 and $292 \mathrm{~kg} \mathrm{~N}^{-1}$. Cylinders were reinstalled at new locations at the beginning of each season to prevent carryover of ${ }^{15} \mathrm{~N}$. The ${ }^{15} \mathrm{~N}$-enriched $\mathrm{KNO}_{3}$ contained 9.75 atom \% excess in 1984 and 1985 , and 9.61 atom \% in 1986 to 1988. Prior to planting, $34 \mathrm{~kg} \mathrm{P}^{-1}$ as $\mathrm{Ca}\left(\mathrm{H}_{2} \mathrm{PO}_{4}\right)_{2}, 140 \mathrm{~kg}$ $\mathrm{K} \mathrm{ha}^{-1}$ as $\mathrm{KCl}$, and $10 \mathrm{~kg} \mathrm{Zn} \mathrm{ha}^{-1}$ as $\mathrm{ZnSO}_{4}$, were applied to ensure fertility levels of these nutrients necessary for an optimal yield (NDSU Ext. Serv., 1992).
Daily precipitation, temperature range, and wind speed and direction were collected at the site during the growing season. Growing degree units (Newman, 1971) were calculated to quantify the annual temperature variation. Growing degree units (GDU) were calculated as

$$
\mathrm{GDU}=\left[\left(T_{\max }+T_{\min }\right) / 2\right]-10
$$

where $T_{\max }$ is the daily maximum temperature, and $T_{\min }$ is the daily minimum temperature. In this calculation, when $T_{\max }$ is $>30^{\circ} \mathrm{C}$, a value of 30 is used. Similarly, when $T_{\min }$ is $<10^{\circ} \mathrm{C}$, a value of 10 is used.

Irrigation water was applied weekly by flooding each cylinder with the appropriate amount of water. Irrigation was initiated when calculated ET exceeded precipitation. Electrical conductivity of the irrigation water was $0.1 \mathrm{~S} \mathrm{~m}^{-1}$ and the sodium adsorption ratio was 4 . Irrigation levels were calculated so that precipitation plus irrigation equaled the desired amount of water. Irrigation treatments in 1984 were $0.6,1.2$, and 1.8 times the calculated ET loss. These treatments were increased to one, two, and three times the calculated ET in subsequent years. ET was calculated using the method of Jensen et al. (1970), with weekly adjustments similar to a crop coefficient from Lundstrom and Stegman (1983). Treatments were replicated three times and arranged in a completely randomized block design.

Corn was harvested shortly after the first killing frost each fall (between 7 and 24 September). The plants were separated into leaves, stalks, and grain, oven dried, and weighed. Results are reported as grain and aboveground dry matter (leaves, stalks, cobs, husks, and grain). Soil cores were taken from each cylinder following harvest and sectioned into $0.05-\mathrm{m}$ increments in 1984 and 1985. Plant and soil samples were digested for total Kjeldahl $\mathrm{N}$ in a block digester using $\mathrm{H}_{2} \mathrm{SO}_{4}$ and $\mathrm{K}_{2} \mathrm{SO}_{4}, \mathrm{FeSO}_{4}$, and $\mathrm{CuSO}_{4}$ (20:2:1 mass basis) as a catalyst (Bremner and Mulvaney, 1982). Subsamples of the digest were sent to Isotope Services in Los Alamos, NM $(1984,1985)$, and to the Nitrogen Isotope Laboratory, University of Nebraska, in Lincoln (19861988) for ${ }^{15} \mathrm{~N}$ analysis. Percentage of plant $\mathrm{N}$ derived from fertilizer (\%NDFF), a measure of the relative amounts of $\mathrm{N}$ the crop obtains from the soil and from applied fertilizer, was calculated as

$$
\% \mathrm{NDFF}=\frac{\%{ }^{15} \mathrm{~N} \text { excess samples }}{\%{ }^{15} \mathrm{~N} \text { excess fertilizer }} \times 100
$$

and percentage utilization of fertilizer $\mathrm{N}$ (\%UFN), a measure of fertilizer use efficiency, was calculated (IAEA, 1976) as

$$
\begin{aligned}
& \text { \%UFN }=\text { \%NDFF } \times \text { Sample total } \mathrm{N} \\
& \text { Fertilizer rate }
\end{aligned}
$$

Differences in yield, $\mathrm{N}$ content, \%NDFF, and \% UFN among the irrigation and $\mathrm{N}$ fertility levels were tested using ANOVA appropriate for a completely randomized block design (SAS Inst., 1990). Plots severely damaged by raccoons in 1988 were treated as missing values in the ANOVA. Differences were declared significant at $P<0.05$. Irrigation level and higher-order interactions involving irrigation level were not significant in the analysis of variance. Data across irrigation levels were therefore pooled to simplify presentation.

\section{RESULTS AND DISCUSSION}

Precipitation was sufficient to meet crop needs early in the growing season and irrigation was not needed prior to 1 July. Precipitation received during the growing season varied from year to year $(\mathrm{CV}=45.9 \%)$. The 1984 rainfall total was 55\% of that received in 1987 (Table 1). Similarly, the amount of irrigation water needed to meet 
Table 1. Growing season precipitation and irrigation amounts applied to the corn crop, and growing degree units (GDU) received at the North Dakota site in the semiarid northern Great Plains.

\begin{tabular}{|c|c|c|c|c|c|}
\hline \multirow[b]{2}{*}{ Year } & \multirow{2}{*}{$\begin{array}{c}\text { Precipi- } \\
\text { tation }\end{array}$} & \multicolumn{3}{|c|}{ Irrigation ${ }^{\dagger}$} & \multirow[b]{2}{*}{ GDU: } \\
\hline & & $1 \mathrm{ET}$ & $2 \mathrm{ET}$ & 3 ET & \\
\hline & & & $\mathrm{m}$ & & \\
\hline 1984 & 156 & 159 & 344 & 512 & 1068 \\
\hline 1985 & 229 & 110 & 360 & 639 & 948 \\
\hline 1986 & 296 & 78 & 318 & 616 & 1040 \\
\hline 1987 & 282 & 135 & 278 & 617 & 1094 \\
\hline 1988 & 186 & 342 & 696 & 1048 & 1193 \\
\hline $30-y r$ avg. & 268 & & & & 1050 \\
\hline
\end{tabular}

+ Precipitation plus irrigation equals one, two, and three times the calculated Jensen-Haise evapotranspiration (ET), except in 1984, when irrigation equalled $0.6,1.2$, and 1.8 times ET.

$\ddagger \mathrm{GDU}=\left[\left(T_{\max }+T_{\min }\right) / 2\right]-10$, where $T_{\max }$ is the daily maximum temperature, and $T_{\min }$ is the daily minimum temperature. When $T_{\max }$ is $>30^{\circ} \mathrm{C}$, a value of 30 is used; when $T_{\min }$ is $<10^{\circ} \mathrm{C}$, a value of 10 is used.

ET varied from year to year (Table 1). Growing degree units during 1985 , the coolest year of the study, were $20 \%$ lower than in 1988, the warmest year of the study (Table 1). Temperatures were below the 30 -yr average during most of the growing season in 1984 and 1985 . Temperatures during June and July of 1988 were 3.6 to $6.5^{\circ} \mathrm{C}$ above the 30 -yr average.

\section{Yield and Nitrogen Content}

Grain yield varied from year to year $(P<0.001)$ (Table 2$)$, probably as a result of the annual variations in temperature common to the northern Great Plains (Table 1). In addition, grain yields in 1988 were severely reduced by raccoon (Procyon lotor) predation.

During years when grain yields were low (1985), there were no yield differences between the $\mathrm{N}$ fertility treatments. This suggests that during cool years temperature influenced grain fill to a greater degree than did $\mathrm{N}$ fertility. In 1986 and 1987, grain yields from the high $\mathrm{N}$ fertility treatment were 1.5 times those from the low $\mathrm{N}$ fertility treatment (Table 2). This differential response resulted in a significant year $\times \mathrm{N}$ treatment interaction $(P<0.05)$ in the analysis of variance. Trends in grain yield for this study are similar to those exhibited by corn grown in the adjacent lysimeters (Reichman and Trooien, 1993).

Yearly variation in aboveground dry matter production was similar to that for grain yield (Table 2). Greatest aboveground dry matter yields were obtained in 1985, 1986, and 1987. Below-normal temperatures during the growing season in 1985 resulted in high aboveground dry matter production but low grain yield (Table 2). Grain filling appears to be more sensitive to temperature than is vegetative growth. Aboveground dry matter production exhibited a greater response to $\mathrm{N}$ fertility than did grain yield. Aboveground dry matter production increased as $\mathrm{N}$ fertility increased during all years except 1988 (significant year $\times \mathrm{N}$ treatment interaction $P<0.001$ ). Low aboveground dry matter production in 1988 was due to the raccoon predation noted above. Trends in aboveground dry matter production for this study are similar to those exhibited by corn grown in the adjacent lysimeters (Reichman and Trooien, 1993).

Grain and aboveground dry matter $\mathrm{N}$ content exhibited yearly variation $(P<0.001)$ (Table 2$)$. These variables responded dramatically to increases in $\mathrm{N}$ fertility $(P<$ $0.001)$. Grain and aboveground $\mathrm{N}$ content from plots fertilized to a $\mathrm{N}$ fertility level of $200 \mathrm{~kg} \mathrm{ha}^{-1}$ were nearly twice that from plots fertilized to a $\mathrm{N}$ fertility of $100 \mathrm{~kg}$ $\mathrm{ha}^{-1}$ (Table 2). Olson (1980) reported similar increases in grain and aboveground $\mathrm{N}$ content with increasing $\mathrm{N}$ fertility for irrigated corn in Kansas. Irrigation level did not affect grain and aboveground $\mathrm{N}$ content $(P>0.10)$ (Table 2).

\section{Fertilizer Use Efficiency}

Nearly $50 \%$ of the $\mathrm{N}$ contained in aboveground dry matter and grain was derived from fertilizer (Table 3). Bigeriego et al. (1979) also found that the percentage of $\mathrm{N}$ derived from fertilizer was similar between grain and aboveground dry matter. The percentage of $\mathrm{N}$ derived from fertilizer varied from year to year $(P<0.001)$, and was likely the result of annual variation in temperature and the effect of temperature on plant development and $\mathrm{N}$ uptake (Moraghan and Porter, 1975). During 1985, when temperatures during the growing season were below average, percentage of $\mathrm{N}$ derived from fertilizer was $80 \%$ that of years when temperatures were near normal (1986, 1987). In addition, $N$ fertility strongly influenced the

Table 2. Grain and aboveground dry matter (DM) yield and $\mathbf{N}$ content (mean \pm SE) for irrigated corn grown at two $\mathbf{N}$-fertility levels in the northern Great Plains.

\begin{tabular}{|c|c|c|c|c|c|}
\hline \multirow[b]{2}{*}{ Year } & \multirow{2}{*}{$\begin{array}{c}\mathbf{N} \text { fertility } \\
\text { level }\end{array}$} & \multicolumn{2}{|c|}{ Yield } & \multicolumn{2}{|c|}{$\mathbf{N}$ content } \\
\hline & & Grain & DM & Grain & DM \\
\hline & $\mathrm{kg} \mathrm{ha}^{-1}$ & $\longrightarrow$ & . & & \\
\hline $1984 \dagger$ & $\begin{array}{l}100 \\
200\end{array}$ & $\begin{array}{l}309 \pm 38 \\
389 \pm 43\end{array}$ & $\begin{array}{l}736 \pm 57 \\
891 \pm 70\end{array}$ & $\begin{array}{l}5.8 \pm 0.7 \\
7.3 \pm 0.8\end{array}$ & $\begin{array}{r}9.0 \pm 0.9 \\
11.2 \pm 1.1\end{array}$ \\
\hline 1985 & $\begin{array}{l}100 \\
200\end{array}$ & $\begin{array}{l}279 \pm 59 \\
338 \pm 73\end{array}$ & $\begin{array}{l}1036 \pm 56 \\
1393 \pm 94\end{array}$ & $\begin{array}{l}4.7 \pm 0.7 \\
6.9 \pm 1.3\end{array}$ & $\begin{array}{r}9.2 \pm 0.6 \\
14.7 \pm 1.3\end{array}$ \\
\hline 1986 & $\begin{array}{l}100 \\
200\end{array}$ & $\begin{array}{l}459 \pm 30 \\
775 \pm 65\end{array}$ & $\begin{array}{r}986 \pm 48 \\
1655 \pm 78\end{array}$ & $\begin{array}{l}4.6 \pm 0.3 \\
9.0 \pm 0.5\end{array}$ & $\begin{array}{r}6.6 \pm 0.4 \\
12.8 \pm 0.3\end{array}$ \\
\hline 1987 & $\begin{array}{l}100 \\
200\end{array}$ & $\begin{array}{l}549 \pm 16 \\
833 \pm 43\end{array}$ & $\begin{array}{l}1274 \pm 30 \\
1866 \pm 49\end{array}$ & $\begin{array}{r}6.0 \pm 0.2 \\
11.1 \pm 0.4\end{array}$ & $\begin{array}{r}8.7 \pm 0.3 \\
15.8 \pm 0.3\end{array}$ \\
\hline $1988 \ddagger$ & $\begin{array}{l}100 \\
200\end{array}$ & $\begin{array}{l}258 \pm 34 \\
437 \pm 86\end{array}$ & $\begin{array}{l}712 \pm 44 \\
897 \pm 74\end{array}$ & $\begin{array}{l}3.4 \pm 0.5 \\
6.5 \pm 1.0\end{array}$ & $\begin{array}{l}4.8 \pm 0.6 \\
7.0 \pm 1.1\end{array}$ \\
\hline LSD (0.05) & & 140 & 169 & 2.0 & 2.2 \\
\hline
\end{tabular}

$\dagger$ Actual treatments in 1984 were $0.6,1.2$, and 1.8 times the calculated ET and 166 and $292 \mathrm{~kg} \mathrm{~N} \mathrm{ha}^{-1}$.

$\ddagger$ Yields reduced due to severe raccoon predation. 
Table 3. Percentage of $\mathbf{N}$ derived from fertilizer (\%NDFF) and percentage utilization of fertilizer $N$ (\%UFN) by grain and aboveground dry matter (DM) (mean \pm SE) for irrigated corn grown at two N-fertility levels in the northern Great Plains.

\begin{tabular}{|c|c|c|c|c|c|}
\hline \multirow[b]{2}{*}{ Year } & \multirow{2}{*}{$\begin{array}{c}N \text { fer- } \\
\text { tility } \\
\text { level }\end{array}$} & \multicolumn{2}{|c|}{$\%$ NDFF } & \multicolumn{2}{|c|}{ \%UFN } \\
\hline & & Grain & DM & Grain & DM \\
\hline & $\mathrm{kg} \mathrm{ha}^{-1}$ & & - & & \\
\hline $1984 \S$ & $\begin{array}{l}100 \\
200\end{array}$ & $\begin{array}{l}56 \pm 5 \\
62 \pm 2\end{array}$ & $\begin{array}{l}52 \pm 5 \\
57 \pm 2\end{array}$ & $\begin{array}{l}32 \pm 4 \\
33 \pm 3\end{array}$ & $\begin{array}{l}45 \pm 5 \\
48 \pm 4\end{array}$ \\
\hline 1985 & $\begin{array}{l}100 \\
200\end{array}$ & $\begin{array}{l}28 \pm 1 \\
47 \pm 3\end{array}$ & $\begin{array}{l}28 \pm 2 \\
48 \pm 3\end{array}$ & $\begin{array}{l}27 \pm 4 \\
22 \pm 4\end{array}$ & $\begin{array}{l}52 \pm 4 \\
48 \pm 4\end{array}$ \\
\hline 1986 & $\begin{array}{l}100 \\
200\end{array}$ & $\begin{array}{l}35 \pm 1 \\
58 \pm 1\end{array}$ & $\begin{array}{l}36 \pm 1 \\
58 \pm 1\end{array}$ & $\begin{array}{l}46 \pm 1 \\
54 \pm 3\end{array}$ & $\begin{array}{l}70 \pm 4 \\
77 \pm 2\end{array}$ \\
\hline 1987 & $\begin{array}{l}100 \\
200\end{array}$ & $\begin{array}{l}38 \pm 1 \\
57 \pm 2\end{array}$ & $\begin{array}{l}39 \pm 1 \\
58 \pm 2\end{array}$ & $\begin{array}{l}36 \pm 1 \\
39 \pm 2\end{array}$ & $\begin{array}{l}53 \pm 1 \\
57 \pm 2\end{array}$ \\
\hline 1988 & $\begin{array}{l}100 \\
200\end{array}$ & $\begin{array}{l}35 \pm 2 \\
58 \pm<1\end{array}$ & $\begin{array}{l}41 \pm 2 \\
48 \pm 4\end{array}$ & $\begin{array}{l}28 \pm 6 \\
26 \pm 6\end{array}$ & $\begin{array}{l}43 \pm 7 \\
23 \pm 5\end{array}$ \\
\hline LSD (0.05) & & 7 & 7 & 9 & 12 \\
\hline
\end{tabular}

$\dagger$ Actual treatments in 1984 were $0.6,1.2$, and 1.8 times the calculated ET and 166 and $292 \mathrm{~kg} \mathrm{~N} \mathrm{ha}{ }^{-1}$.

amount of plant $\mathrm{N}$ derived from fertilizer $(P<0.001)$, with much greater percentages of plant $\mathrm{N}$ being derived from fertilizer in the $200 \mathrm{~kg} \mathrm{ha}^{-1}$ plots than in the $100 \mathrm{~kg} \mathrm{ha}^{-1}$ plots (Table 3). Others have reported an increase in percentage $\mathrm{N}$ derived from fertilizer with increasing fertilizer $\mathrm{N}$ rates (Bigeriego et al., 1979; Legg et al., 1979; Hill et al., 1983; Meisinger et al., 1985).

Grain utilized about $35 \%$ and stover utilized an additional $15 \%$ of the applied fertilizer (Table 3 ). The percentage utilization of fertilizer $\mathrm{N}$ varied across years $(P<0.001)$ (Table 3), being greater in years when growing season temperatures were favorable for corn growth (1986 and $1987)$ than in less favorable years $(1984,1985$, and 1988). While the difference in utilization of fertilizer $\mathrm{N}$ between $\mathbf{N}$ fertility treatments was not significant, there was a distinct trend. In years when temperatures were favorable for corn growth (1986 and 1987), percentage utilization of fertilizer $\mathrm{N}$ increased as $\mathrm{N}$ fertility increased, while in cool (1985) or hot (1988) years the percentage utilization of fertilizer $\mathrm{N}$ was higher at lower $\mathrm{N}$ fertility levels (significant year $\times \mathrm{N}$ fertility treatment interaction, $P<$ 0.005 ) (Table 3). During cool years, corn growth was reduced and the crop was unable to utilize the available fertilizer.

Fertilizer $\mathrm{N}$ recovery in the soil at the end of the growing season exhibited a similar pattern during the $2 \mathrm{yr}$ that samples were taken (Fig. 1). Greater amounts of fertilizer $\mathrm{N}$ were present in the soil in 1984 than in 1985, reflecting the higher $\mathrm{N}$ application rates and lower levels of irrigation used during the first year of the study. Most of the fertilizer $\mathrm{N}$ remained in the upper $0.25 \mathrm{~m}$ of the soil. However, small amounts of fertilizer N ( 1 to $2 \%$ of that applied) were found in each increment throughout the sampled profile, demonstrating that $\mathrm{NO}_{3}-\mathrm{N}$ was being leached through the soil profile.

Irrigation level did not affect either the distribution of fertilizer $\mathbf{N}$ in the sampled soil profile or the total amount of fertilizer $\mathrm{N}$ remaining in the sampled soil profile $(P>$ $0.10)$. Since irrigation was not applied for 5 or $6 \mathrm{wk}$ after fertilizer application, it appears that immobilization or uptake of fertilizer $\mathrm{N}$ reduced the potential for leaching. These results also suggest that water inputs at the lowest

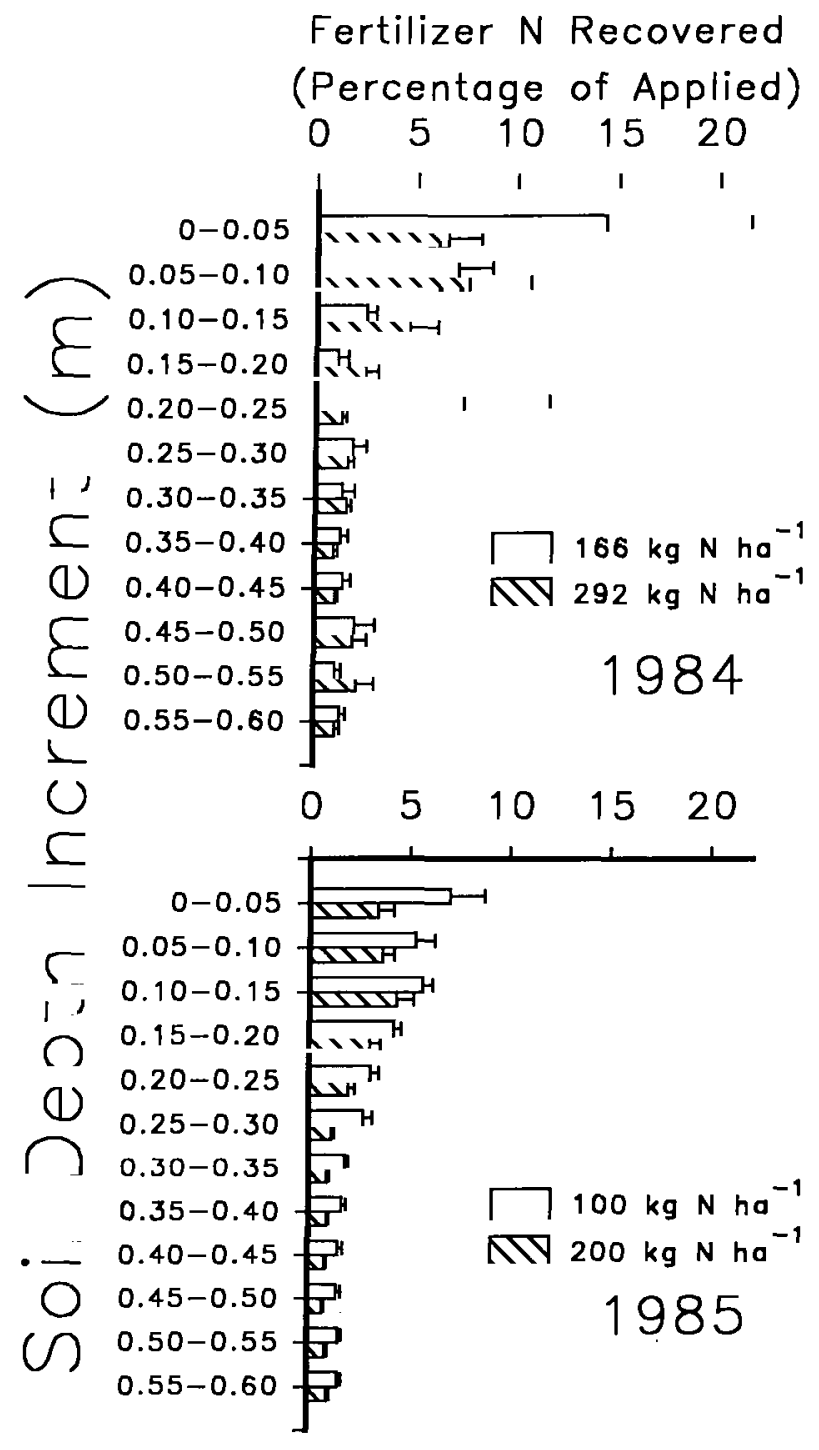

Fig. 1. Recoyery of applied fertilizer $\mathbf{N}$ as a function of depth for soil under irrigated corn in the northern Great Plains. Error bars represent 1 SE.

level of irrigation were sufficient to move the leachable fraction below $0.6 \mathrm{~m}$.

A mass balance for fertilizer $\mathrm{N}$ reveals that $30 \%$ remained in the upper $0.6 \mathrm{~m}$ of soil, $35 \%$ was taken up by the grain, and $15 \%$ was taken up by the stover leaving $20 \%$ of the applied fertilizer $\mathrm{N}$ unaccounted for. Nitrate $\mathrm{N}$ has a high water solubility, and the potential existed for considerable leaching. Olson (1980) found that $24 \%$ of the fertilizer $\mathrm{N}$ applied to irrigated corn in Kansas could not be accounted for in the soil-plant system after $2 \mathrm{yr}$. Similarly, Gerwing et al. (1979) found substantial amounts of $\mathrm{NO}_{3}-\mathrm{N}$ in the soil solution below the root zone of irrigated corn. In addition, greater soil water contents under irrigation may result in losses of fertilizer $\mathrm{N}$ due to denitrification.

These results demonstrate that favorable corn yields can be obtained using supplemental irrigation in the northern Great Plains. Grain and aboveground dry matter yields did not respond to irrigation level $(P>0.10)$. In an adjacent field, nonirrigated corn produced 53\% as much bio- 
mass in 1985 and $85 \%$ as much biomass in 1986 as corn receiving irrigation equal to evapotranspiration (S.D. Merrill, unpublished data, 1987). This suggests that the lowest irrigation level used in the present study was sufficient to meet the needs of the crop and higher levels were not necessary. In addition, yields were not depressed at higher levels of irrigation, suggesting that waterlogging or salinization of the root zone did not occur. These results confirm that the natural drainage potential of these soils is sufficient to support irrigation (Trooien and Reichman, 1993), and is sufficient to allow leaching to prevent salt accumulation in the root zone (Reichman and Trooien, 1993).

Supplemental irrigation appears to be a viable technology for growing corn in the northern Great Plains if care is taken to ensure that irrigation inputs are optimized to prevent nutrient leaching from the root zone. A recent economic analysis has calculated that supplemental irrigation is economical in certain areas of North Dakota (Leitch et al., 1991). Year-to-year variation in precipitation exerts a strong influence on crop yields in the northern Great Plains. This technology is available to producers who wish to stabilize crop production or grow crops requiring water in excess of that normally available in this semiarid region.

\section{ACKNOWLEDGMENTS}

The authors thank Wallace Sellner for maintaining the field site and the Burleigh County Water Resources District for supplying equipment and access to the site.

\section{REFERENCES}

Bigeriego, M., R.D. Hauck, and R.A. Olson. 1979. Uptake, translocation, and utilization of ${ }^{15} \mathrm{~N}$-depleted fertilizer in irrigated corn. Soil Sci. Soc. Am. J. 43:528-533.

Bremner, J.M., and C.S. Mulvaney. 1982. Nitrogen: Total. p. 595-624. In A.L. Page (ed.) Methods of soil analysis. Part 2. 2nd ed. Agron. Monogr. 9. ASA and SSSA, Madison, WI.

Chang, C., G.C. Kozub, and D.C. Mackay. 1985. Soil salinity status and its relation to some of the soil and land properties of three irrigation districts in southern Alberta. Can. J. Soil Sci. 65:187-193.

Doering, E.J., L.C. Benz, and G.A. Reichman. 1986. Internal drainage of fine-textured alluvial subsoils in North Dakota. Trans. ASAE 29:517-521.
Gerwing, J.R., A.C. Caldwell, and L.L. Goodroad. 1979. Fertilizer nitrogen distribution under irrigation between soil, plant, and aquifer. J. Environ. Qual. 8:281-284.

Hill, F.J., F.E. Broadbent, and O.A. Lorenz. 1983. Fertilizer nitrogen utilization by corn, tomato, and sugarbeet. Agron. J. 75:423-426.

International Atomic Energy Agency. 1976. Tracer manual on crops and soils. Tech. Rep. 171. IAEA and FAO, Vienna.

Jensen, M.E., D.C.N. Robb, and C.E. Franzoy. 1970. Scheduling ir rigations using climate-crop-soil data. J. Irrig. Drain. Div. Am. Soc. Civ. Eng. 96:25-38.

Keeney, D.R. 1982. Nitrogen management for maximum efficiency and minimum pollution. p. 605-649. In F.J. Stevenson (ed.) Nitrogen in agricultural soils. Agron. Monogr. 22. ASA, CSSA, and SSSA, Madison, WI.

Legg, J.O., G. Stanford, and O.L. Bennett. 1979. Utilization of labeled$\mathrm{N}$ fertilizer by silage corn under conventional and no-till culture. Agron. J. 71:1009-1015.

Leitch, J.A., J.F. Baltezore, R.G. Johnson, and R.C. Coon. 1991. A reevaluation of Garrison Diversion Unit irrigation. Project Rep. Garrison Diversion Conservancy District, Carrington, ND.

Lundstrom, D.R., and E.C. Stegman. 1983. Irrigation scheduling by the checkbook method. North Dakota Ext. Publ. AE-792. North Dakota State Univ., Fargo.

Marschner, H. 1986. Mineral nutrition in higher plants. Academic Press, Orlando, FL.

Meisinger, J.J., V.A. Bandel, G. Stanford, and J.O. Legg. 1985. Nitrogen utilization of corn under minimal tillage and moldboard plow tillage: I. Four-year results using labeled $\mathrm{N}$ fertilizer on an Atlantic Coastal Plain soil. Agron. J. 77:602-611.

Moraghan, J.T., and O.A. Porter. 1975. Maize growth as affected by root temperature and form of nitrogen. Plant Soil 43:479-487.

Newman, J.E. 1971. Measuring corn maturity with heat units. Crops Soils 23:11-14.

North Dakota State University Extension Service. 1992. Crop production guide no. 2. North Dakota State Univ., Fargo.

Olson, R.V. 1980. Fate of tagged nitrogen fertilizer applied to irrigated corn. Soil Sci. Soc. Am. J. 44:514-517.

Reichman, G.A., and T.P. Trooien. 1993. Corn yield and salinity response to irrigation on slowly permeable subsoils. Soil Sci. Soc. Am. J. 57:1549-1554.

SAS Institute. 1990. SAS/STAT guide for personal computers. Version 6 ed. SAS Inst., Cary, NC.

Schrader, L.E., D. Domska, P.E. Jung, Jr., and L.A. Peterson. 1972. Uptake and assimilation of ammonium- $\mathrm{N}$ and nitrate- $\mathrm{N}$ and their influence on the growth of corn (Zea mays L.). Agron. J. 64:690-695.

Trooien, T.P., and G.A. Reichman. 1990. Hydraulic conductivity of till subsoil in North Dakota. Trans. ASAE 33:1492-I496.

Trooien, T.P., and G.A. Reichman. 1993. Internal drainage under irrigation of two slowly permeable subsoils of the northern Great Plains. Trans. ASAE 36:709-715.

U.S. Department of Interior, Bureau of Reclamation. 1993. Drainage manual. U.S. Gov. Print. Office, Washington, DC. 